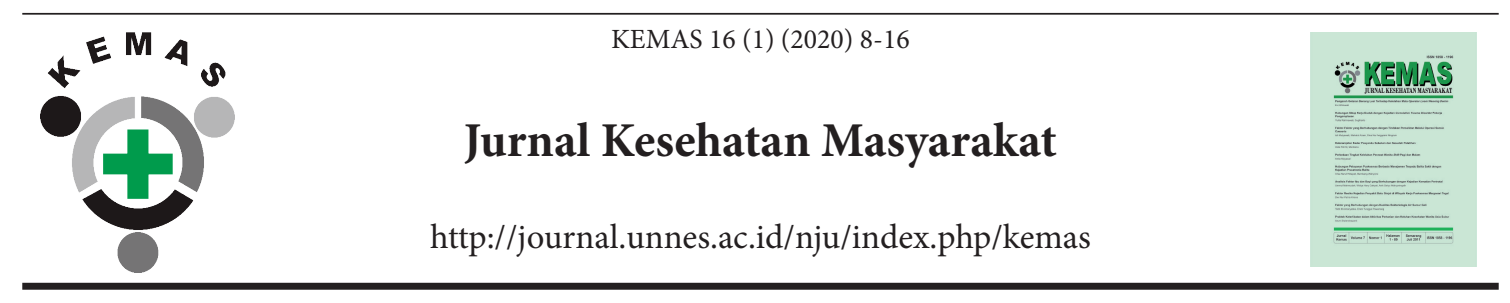

\title{
Violence Determinant on Teenagers in Yogyakarta
}

Erni Gustina ${ }^{\bowtie}$, Liena Sofiana, Suci Musvita Ayu, Marsiana Wibowo, Inggrid Dwita Wardani

Public Health Department, Universitas Ahmad Dahlan, Yogyakarta, Indonesia

\section{Article Info}

Article History:

Submitted Mei 2018

Accepted April 2020

Published July 2020

Keywords:

Determinant,

Violence, Teenager

DOI

https://doi.org/10.15294/

kemas.v16il.14323

\begin{abstract}
Violence can adversely affect teenagers. Teenagers rarely report violence to their friends or family. Teens who are experienced with violent outbreaks have symptoms such as depression and anxiety, deviant behaviours such as smoking, drugs and alcohol and even attempted suicide. This Study used a cross-sectional design. The sample of the study were student aged 15-19 years who came from 18 Junior High School in Yogyakarta City. The study was conducted during August 2017. Sample size is 481 adolescents. Technique sampling used multistage random cluster sampling. The instrument used questionnaires on violence, knowledge, attitudes, self-confidence, family roles, peer roles, teacher roles and information sources. Data analysis used univariate and bivariate analysis used chi square test. Results showed that $77.5 \%$ of adolescents were violent and $68.4 \%$ were physically abused. Peers are a risk factor for adolescents to engage in violence (PR: 1.335; CI 95\%:1.205-1.479) and families also play an important role for adolescents engaged in violence (PR: 1.179; CI 95\%: 1.079-1.292). The existence of teen counseling services such as Youth Information and Counseling Center to increase adolescent insight about juvenile delinquency especially violence and impact on adolescents.
\end{abstract}

\section{Introduction}

Teenage is a period when ones are faced with various conflicts that occur due to changes that exist in themselves. Such physical, emotional, and social changes, the changes can conflict with the surrounding environment. Teenager has many problems and pressures experienced related with these changes. Violence is one thing that is common among teenagers. Violence is a big problem, because it can have both short and long term impacts. Teenagers rarely report the violence they experience to friends and family. Among high school students, $21 \%$ of female and $10 \%$ of male have experienced physical or sexual violence. Among teenagers who experienced rape and physical violence committed by their partners, $22 \%$ of female and $15 \%$ of male who experienced it came from couples aged between 11-17 years. A national survey conducted by
(Finkelhor et al., 2015), found that $40 \%$ of teenagers aged 17 years or younger had been exposed to at least one form of violence during their lives such as assault or physical abuse.

Teenagers who are experienced with violent incidents have symptoms such as depression and anxiety, deviant behavior such as smoking, drugs and alcohol even trying to commit suicide (World Health Organization, 2015). The results of the study mentioned that the symptoms of depression are a result of violence that occurs in the family environment. Good communication between mother and teenager gives a positive impact in reducing violent behavior in teenager (Eisman et al., 2015). Research (Heinze et al., 2018), found a positive and strong relation between violence in teenagers with depressive symptoms as adults. Teenagers living in low-income environments are more likely to be exposed to violence and 
increase their risk of mental health (Voisin et al., 2016). Children who experience violence or witness violence have a higher risk of such behavior during adulthood (Fulu et al., 2013; Fleming et al., 2015; Jennings et al., 2015).

Based on the fact sheet annual records (Catahu), in 2015 the number of cases of violence against women reached 321,752 cases. One of the perpetrators who committed violence against women was carried out by intimate relations with the victim. A total of 11,207 cases were committed by those having close relation with the victim, 2,734 cases (24\%) of which were dating violence. Kind of violence against women included physical as many as 4,304 cases (38\%), followed by sexual 3,325 cases $(30 \%)$, psychological 2,607 cases $(23 \%)$, and economic 971 cases (9\%) (Komisi Nasional Perempuan, 2016).

Violence by teenagers is a serious problem that must be a concern for all people. The impact is short term and long term which can affect physical and psychological conditions for the victims. According to (Green and Kouter, 2000), there are several factors that affect behavior namely predisposing factors (knowledge, beliefs, values, attitudes and faith), enabling factors (availability of health resources, easy access to health resources, community/government regulations, priorities and commitment to health and health-related skills) and reinforcing factors (parents, teachers, peers). Based on the background that has been described, it drives the attention of researcher to examine the relationship between predisposing, enabling and reinforcing factors with violence by teenagers in the city of Yogyakarta.

Method

This research was an observational analytic cross-sectional design. It was conducted in August 2017. The population were all students from 80 Senior High Schools in Yogyakarta with a total of 36,360 people. The research sample was students aged 15-19 years. The sample size was 481 students drawn from 18 schools. The sampling technique used multistage random cluster sampling.

The instrument used was a questionnaire about violence, knowledge, attitudes, selfconfidence, the role of family, the role of peers, the role of teachers and sources of information.
The research questionnaire was tested for validity at the PIRI Vocational High School in Yogyakarta City and was tested for validity and reliability using corrected item-total correction. Some of the questionnaires used in this study were modifications of several studies. Modified violence questionnaire from (Ayu, Hakimi and Hayati, 2012) and (Sulistyowati, 2014) with a Cronbach a value of 0.887 ; Knowledge modification of (Sulistyowati, 2014), with a Cronbach a value of 0.602; Modification of attitude (Lubis, S, 2012), with a Cronbach a value of 0.819; Modified confidence from (Pratama, 2016), with a Cronbach $\alpha$ value of 0.604 ; The role of the family ( $\alpha$ Cronbach: 0,612 ); The role of the teacher ( $\alpha$ Cronbach: 0,671); The role of peers modification from Lubis (2010) and (Susanti, 2012), with a Cronbach a value of 0.697 .

Data analysis included univariate and bivariate analysis. Univariate analysis was carried out to describe the variables studied, namely knowledge, attitudes, self-confidence, family roles, peer roles, teacher roles and information sources with results in the form of frequency distributions, percentages and narratives of these variables. Bivariate analysis was carried out on two variables to determine the relation between variables, namely the independent variables and the dependent variables. This analysis used the Chi-Square test ( $p$ <0.05). Prevalence Ratio (PR) was used to calculate the risk of the independent variables and the dependent variables.

\section{Result and Discussion}

The number of respondents in this study were 481 students taken from 18 high schools in the city of Yogyakarta. Respondents' characteristics were based on age, sex, parental past education and types of violence. Of the 481 respondents, the age of most respondents was 16 years as many as 231 students (48\%). The minimum age of the respondent was 15 years and the maximum age of the respondent was 19 years. The number of female respondents were $245(50.9 \%)$ and the number of male respondents were 236 (49.1\%). The highest level of parental education was High School with 216 people $(44.9 \%)$ while the lowest of parental education was Elementary School with 26 people (5.4\%). The most common type of 
Table 1. Characteristics of respondents

\begin{tabular}{lll}
\hline Characteristics of respondents & Frequency & Percentage (\%) \\
\hline Age & 85 & 17,7 \\
15 & 231 & 48,0 \\
16 & 118 & 24,5 \\
17 & 41 & 8,5 \\
18 & 6 & 1,2 \\
19 & & \\
Gender & 236 & 49,1 \\
Male & 245 & 50,9 \\
Female & & \\
Parent education & 62 & 12,9 \\
Unknown & 26 & 5,4 \\
Elementary & 36 & 7,5 \\
Junior High & 216 & 44,9 \\
Senior High & 141 & 29,3 \\
Graduate & & \\
Form of Violence & 329 & 68,4 \\
Physical & 292 & 60,7 \\
Psychological & 73 & 15,2 \\
Economical & 18 & 3,7 \\
Sexual & 481 & 100 \\
\hline Total & &
\end{tabular}

Source: Primary Data, 2017

violence perpetrated by teenagers was physical violence $(68.4 \%)$ while the least type of violence was sexual one $(3.7 \%)$. The data can be seen in Table 1.

From 481 respondents, $70.7 \%$ have high knowledge about violence. Respondents with negative attitudes to violence were 245 students (50.9\%). Some respondents had self-confidence as many as 346 students (71.9\%). Respondents with access to low sources of information were 239 students (49.7\%). As many as 341 respondents (70.9\%) stated that the family's role was not to commit violence. A total of 308 respondents $(63.6 \%)$ stated that teachers have a role for respondents not to do violence. Respondents who were influenced by peers to commit violence were 308 students (63.6\%). As many as $77.5 \%$ of teenagers have experienced violence. Univariate analysis results can be seen in Table 2.

Bivariate analysis in this study used the chi square test. The results of this study indicate that there is a relationship between the role of parents $(\mathrm{p}=0.003)$ and the value of $P R$ 1.179 (95\% CI: 1.079-1.292) which means that teenagers who have less family role have a risk of 1,179 times to commit violence greater than teenagers who has a family that plays a good role. The role of peers has a relationship with violence in teenagers $(p=0,000)$ and a value of PR 1,335 (95\% CI: 1,205-1,479) which means that teenagers who have a peer who have a high role have a risk of 1,335 times greater for violence than teenagers with Peers with less role. While there is no relationship between knowledge $(\mathrm{p}=0.136)$, attitudes $(\mathrm{p}=0.740)$, self-confidence $(p=0.174)$, teacher's role $(p$ $=0.213)$, information sources $(\mathrm{p}=0.055)$ and violence by teenagers. The results of the chi square analysis can be seen in Table 3 .

Good knowledge should encourage teenagers not to commit violence. In this study, 
Table 2. Distribution of variables frequency

\begin{tabular}{lcc}
\hline Variables & Frequency & Percentage (\%) \\
\hline Knowledge & & \\
Poor & 141 & 29,3 \\
Well & 340 & 70,7 \\
Attitude & & \\
Negative & 245 & 50,9 \\
Positive & 236 & 49,1 \\
Self Confidence & & \\
Lack & 135 & 28,1 \\
Confidence & 346 & 71,9 \\
Family Role & & \\
Less & 239 & 49,7 \\
Have a role & 341 & 50,3 \\
Teacher role & & \\
Less & 140 & 29,1 \\
Have a role & 341 & 70,9 \\
Peer Role & & \\
Less & 175 & 36,4 \\
Have a role & 308 & 63,6 \\
Source of information & & \\
Low & 243 & 50,5 \\
High & 238 & 49,5 \\
Violence & & \\
Yes & 373 & \\
No & 108 & \\
\hline Total & 481 & \\
\hline Source Primary & & \\
\hline & & \\
\hline
\end{tabular}

Source: Primary Data, 2017

teenagers knowledge is only limited to know. This is in line with the notion of knowledge according to (Notoatmodjo, 2010), which stated that knowledge is the result of human sensing or the result of knowing the object through its senses. Teenagers are only limited to knowing the related types, rules and effects of violence without applying it in real life so that they still continue to commit violence. This is likely caused by other factors that affect it.

Previous research showed that there is a relation between knowledge and violence, meaning that the higher the level of knowledge of teenagers about violence, the lower the incidence of violence. Conversely the lower the level of teenager knowledge about violence, the higher the incidence of violence. Thus teenagers with high knowledge are expected to become protectors for themselves from violence (Sulistyowati, 2014). Research (Hidayangsih et al., 2011), stated there is a negative relation between knowledge and risk behaviors of teenagers where the higher the knowledge, the higher the drive for risky behavior, one of which is violence.

Based on this research it can be seen that teenagers with high knowledge are not necessarily ones who are positive about violence by not doing violence to others. Negative attitudes in this research are various perceptions, opinions, judgments and desires to commit violence. But in teenagers attitudes toward violence both negative and positive attitudes have a not much different percentage 
Table 3. Chi Square Test Result between independent variables and dependent variables

\begin{tabular}{|c|c|c|c|c|c|c|c|c|}
\hline \multirow{3}{*}{ Variable } & \multicolumn{4}{|c|}{ Violence } & \multicolumn{2}{|c|}{ Total } & \multirow{3}{*}{$P$ value } & \multirow{3}{*}{ PR (CI 95\%) } \\
\hline & \multicolumn{2}{|l|}{ Yes } & \multicolumn{2}{|l|}{ No } & \multirow{2}{*}{$\mathrm{n}$} & \multirow{2}{*}{$(\%)$} & & \\
\hline & $\mathrm{n}$ & (\%) & $\mathrm{n}$ & $(\%)$ & & & & \\
\hline \multicolumn{9}{|l|}{ Knowledge } \\
\hline Poor & 102 & 21,2 & 39 & 8,1 & 141 & 29,3 & 0,136 & $0,914(0,814-1,027)$ \\
\hline Well & 269 & 55,9 & 71 & 14,8 & 340 & 70,7 & & \\
\hline \multicolumn{9}{|l|}{ Attitude } \\
\hline Negative & 191 & 39,7 & 54 & 11,2 & 245 & 50,9 & 0,740 & $1,022(0,927-1,127)$ \\
\hline Positive & 180 & 37,4 & 56 & 11,6 & 236 & 49,1 & & \\
\hline \multicolumn{9}{|c|}{ Self Confidence } \\
\hline Lack & 98 & 20,4 & 37 & 7,7 & 135 & 28,1 & 0,174 & $0,920(0,818-1,034)$ \\
\hline Confidence & 273 & 56,8 & 73 & 15,2 & 346 & 71,9 & & \\
\hline \multicolumn{9}{|l|}{ Family Role } \\
\hline Less & 121 & 25,2 & 19 & 4 & 140 & 29,1 & 0,003 & $1,179(1,079-1,292)$ \\
\hline Have a role & 250 & 52 & 91 & 18,9 & 341 & 70,9 & & \\
\hline \multicolumn{9}{|c|}{ Teacher Role } \\
\hline Less & 141 & 29,3 & 34 & 7,1 & 175 & 36,4 & 0,213 & $1,072(0,973-1,181)$ \\
\hline Have a role & 230 & 47,8 & 76 & 15,8 & 306 & 63,6 & & \\
\hline \multicolumn{9}{|l|}{ Family Role } \\
\hline Have a role & 214 & 44,5 & 29 & 6 & 243 & 50,5 & 0,000 & $1,335(1,205-1,479)$ \\
\hline Less & 157 & 32,6 & 81 & 16,8 & 238 & 49,5 & & \\
\hline \multicolumn{9}{|c|}{ Information Source } \\
\hline Low & 175 & 36,4 & 64 & 13,3 & 239 & 49,7 & 0,055 & $0,904(0,820-0,997)$ \\
\hline High & 196 & 40,7 & 46 & 9,6 & 242 & 50,3 & & \\
\hline
\end{tabular}

Source: Primary Data, 2017

for violence. Thus affecting the results of research with no relation between attitude and violence found. Researchers assume that there are other factors that affect the formation of attitudes, namely knowledge. Research (Sumiati and Lailan, 2012), states that if teenagers knowledge is good, it produces good attitudes. This means that if teenagers have a high level of knowledge about violence, their attitudes to non-violence are also high. Vice versa, if the knowledge of teenagers is low then the attitude to violence is high.

Violence committed by teenagers is also affected by self-confidence. Based on the result, teenagers who feel valued or have high self-confidence are not necessarily non-violent. The researchers' assumption of the result is because teenagers assume that one who commit violence is something that is natural in everyday relation. Another assumption is that there are no complaints from victims of violence as a result of the actions of the perpetrators, so that the perpetrators remain confident and enjoy doing violence against the victims. The results of a study (Fatchurahman and Pratikno, 2012), stated that there is a significant negative relation between self-confidence and juvenile delinquency, where the higher the teenager's self-confidence the lower the juvenile delinquency. Vice versa, the lower the confidence of teenagers, the higher the juvenile delinquency. One's self confidence is affected by self-esteem. Research (Hidayati, 2015), stated that self-confidence has no significant effect on juvenile delinquency. Self-confidencr is a factor related to an individual's internality, how the individual respects himself, the similarity between how a person sees himself positively and the reality that exists.

Other factor that may influence teenagers to commit violence is the role of peers. The intensity of interaction that is more with 
peers and the existence of information shared among them becomes a reinforcing factor for adolescents to commit violence to proof the information they received. The more they interact with at-risk peer, the more likely they are to get involved in the behavior. Research (Lestary and Sugiharti, 2011), suggested that one of the determinants of risk behavior in teenagers is the presence of friends who behave risky. The encouragement and experience together with peers increases teenagers' confidence in committing violence.

The results of a study (Septiyuni, Budimansyah and Wilodati, 2015), stated that there is an effect of peers on student violence at school with a contribution of $13 \%$. The role of peers in violence aims to make these teenagers acceptable in their communities. Other research (Fitriani and Hastuti, 2016), obtained significant result between the influence of peers on juvenile delinquency, one of which is violence. Teenagers have a tendency to do violence if their friends also do it (Bond and Bushman, 2017).

The result of a study indicated that there is a relation between the role of peers with violent behavior where the behavior shown is increasingly strengthened by the praise given by friends and teenagers who dare to commit violence so teenagers feel more valued in their peer groups and respected by other groups of friends (Shofia and Sari, 2016). Peers play a very important role in the formation of teenagers attitudes and behavior. Teenagers who are friends with someone who often acts violently tend to follow that behavior. If a group of peers shows a positive value then the teenager will also show a positive attitude and behavior. Vice versa, if the peer group show negative values, teenagers will show negative attitudes and behaviors (Sulistyowati, 2014).

Family is one of the reinforcing factors in risk behavior. A family with a good relation can affect the behavior, personality development and emotions of teenagers (Sriyanto et al., 2014). Interpersonal communication of teenagers with parents has proven to be influential, good interpersonal communication that is built between parents and teenagers can result in the low violent behavior (Usman, 2013). Family relationships and prosocial norms independently protect girls from violent involvement. Prosocial norms with friends also function as protectors against violence and victimization. However, girls with strong peer connections have higher levels of violence (Shlafer et al., 2014).

The criminal pattern of the father and mother or a family member can print the criminal pattern of almost all family members. There is a significant difference between male and female teenager, male teenager often get physical abuse from fathers more often than female teenage. Meanwhile female teenager more often get verbal abuse from mothers than male teenager. If this violence continues in the family, it is possible that the teenager can become perpetrators of violence in the future (Berlianti et al., 2016). Teenagers who experience violence in the family system are more likely to abuse their peers and can increase violence in adulthood (Xia, Li and Liu, 2018). Teenagers who have witnessed violence committed by parents are predicted to have a direct impact on violence and victimization when they are adults (Franzese et al., 2017).

A teacher can play a role in preventing and alleviating violent behavior in schools. Among roles of the teacher are to provide services to students according to their needs optimally and efficiently. Then collaborating with parents, principals, vice principals, subject teachers and including residents of surrounding schools to provide good supervision for students so that their attitudes and behavior can be controlled (Yandri, 2014). A research (Sulistyowati, 2014), stated that there is a positive relation between the school environment and violent behavior, if the school environment is good then the behavior of teenager tends to be good. (Johnson et al., 2017), suggested that there is a need for agreement in the awareness of building positive perceptions in individuals and the environment against violence can be protective for teenagers not to be involved in violence. School-based health care education interventions can have a positive impact on preventing violence in teenagers (Neto et al., 2014).

A report (World Health Organization, 2015), stated that $92 \%$ of teenagers do not know where to get information and consultations about health, both those in the vicinity of their 
homes and schools or Community Health Service Centre (Puskesmas). The most possible source of information at school can be through the Youth Counseling Information Center (PIK R). However, of the total schools used as research sites, only one school has PIK R and the Violence Task Force. One of the roles of PIK R is to be able to act as a face-to-face media between counselors and teenagers to improve youth information about violence in particular. The function should be able to have a positive impact on them not to commit acts of deviation from values and behavior. A research (Hariyadi, 2016), stated that watching TV and playing games with violent content can cause children to imitate these behaviors, so it is necessary to provide knowledge about the effects of violence. Thus they can control the media they consume without being totally dependent on parents.

\section{Conclussion}

The parents and peers role variables have a relation with violence by teenagers in the city of Yogyakarta, while the variables of knowledge, attitudes, self-confidence, the role of teachers and sources of information have no relation with it.

Teenagers who are at risk should report various acts of violence that can harm themselves or groups to the school and parents to cut acts of violence chain. Among risk factors of violence by teenagers in the city of Yogyakarta is the role of peers. The results of this research should be considered by the Office of Education to include material about risky behavior for teenagers, especially violence in the education materials or school curriculum. Schools are expected to collaborate across sectors to develop youth counseling services such as the Youth Information and Counseling Center (PIKR) in order to broaden teenager insights about the effects of juvenile delinquency, especially violence on teenagers.

\section{Reference}

Ayu, S.M., Hakimi, M., \& Hayati, E.N., 2012. Kekerasan dalam Pacaran dan Kecemasan Remaja Putri di Kabupaten Purworejo. Kesmas, 6(1), pp.61-74.

Berlianti, D., Vitayala, A., Hastuti, D., Sarwoprasodjo, S., \& Krisnatuti, D., 2016. Ada Apa dengan Komunikasi Orang TuaRemaja?: Pengaruhnya Terhadap Agresivitas Remaja pada Sesama. Jur.Ilm. Kelr.\&Kons,
9(3), pp.183-194.

Bond, R.M., \& Bushman, B.J., 2017. The Contagious Spread of Violence Among US Adolescents Through Social Networks. AJPH Research, 107(2), pp.288-294.

Eisman, A.B., Stoddard, S.A., Heinze, J., Caldwell, C.H., \& Zimmerman, M.A., 2015. Depressive Symptoms, Social Support and Violence Exposure Among Urban Youth: A Longitudinal Study of Resilience Andria. Dev Psychol, 51(9), pp.1307-1316.

Fatchurahman, M., \& Pratikno, H., 2012. Kepercayaan Diri, Kematangan Emosi, Pola Asuh Orang Tua Demokratis dan Kenakalan Remaja. Jurnal Psikologi Indonesia, 1(2), pp.77-87.

Finkelhor, D., Turner, H.A., Shattuck, A., \& Hamby, S.L., 2015. Prevalence of Childhood Exposure to Violence, Crime, and Abuse Results From the National Survey of Children's Exposure to Violence. JAMA Pediatrics, 169(8), pp.746-754.

Fitriani, W., \& Hastuti, D., 2016. Pengaruh Kelekatan Remaja dengan Ibu, Ayah, dan Teman Sebaya Terhadap Kenakalan Remaja di Lembaga Pembinaan Khusus Anak (LPKA) Kelas Ii Bandung. Jur.Ilm. Kelr.\&Kons, 9(3), pp.206217.

Fleming, P.J., Mccleary-sills, J., Morton, M., Levtov, R., Heilman, B., \& Barker, G., 2015. Risk Factors for Men's Lifetime Perpetration of Physical Violence against Intimate Partners : Results from the International Men and Gender Equality Survey ( IMAGES ) in Eight Countries. Plos One, 2015,pp.1-18.

Franzese, R.J., Menard, S., Weiss, A.J., \& Covey, H.C., 2017. Adolescent Exposure to Violence and Adult Violent Victimization and Offending. Criminal Justice Review, 42(1), pp.42-57.

Fulu, E., Rachel, P., Mbbs, J., Roselli, T., Garciamoreno, C., \& Study, U.N.M.C., 2013. Prevalence of and Factors Associated with Male Perpetration of Intimate Partner Violence: Findings from the UN Multicountry Cross-sectional Study on Men and Violence in Asia and the Pacific. The Lancet Global Health, 1(4), pp.187-207.

Green, L., \& Kouter, M., 2000. Health Promotion Planning: An Educational and Environmental Approach (Second Edi). California: Mayfield Publishing Company.

Hariyadi., 2016. Dampak Negatif Bermain Game dan Menonton Tayangan Bermuatan Kekerasan Pada Anak (Penyuluhan pada Siswa Sdn 06 Pasar Muara Labuh, Kab. Solok Selatan). Menara Ilmu, X(73), pp.166-176. 
Heinze, J.E., Cook, S.H., Wood, E.P., Dumadag, A.C., \& Zimmerman, M.A., 2018. Friendship Attachment Style Moderates the Effect of Adolescent Exposure to Violence on Emerging Adult Depression and Anxiety Trajectories. J Youth Adolesc, 47(1), pp.177193.

Hidayangsih, P.S., Tjandrarini, D.H., Mubasyiroh, R., \& Supanni., 2011. Faktor-Faktor Yang Berhubungan dengan Perilaku Berisiko Remaja di Kota Makassar Tahun 2009. Bul. Penelit.Kesehatan, 39(2), pp.88-98.

Hidayati, N.A., 2015. Pengaruh Tingkat Pendidikan Orang Tua terhadap Self-Esteem Remaja. In Seminar Psikologi \& Kemanusiaan, pp.978979.

Jennings, W.G., Richards, T.N., Tomsich, E., Gover, A.R., Jennings, W.G., Richards, T.N., Richards, T.N., 2015. Investigating the Role of Child Sexual Abuse in Intimate Partner Violence Victimization and Perpetration in Young Adulthood From a Propensity Score Matching Approach Investigating the Role of Child Sexual Abuse in Intimate Partner Violence Victimization. Journal Od Child Sexual Abuse, 8712(February 2016).

Johnson, S.L., Reichenberg, R., Bradshaw, C.P., Haynie, D.L., \& Cheng, T.L., 2017. Caregiver and Adolescent Discrepancies in Perceptions of Violence and their Associations with Early Adolescent Aggression. J Youth Adolesc, 45(10), pp.2125-2137.

Komisi Nasional Perempuan., 2016. Lembar Fakta Catatan Tahunan (Catahu).

Lestary, H., \& Sugiharti., 2011. Perilaku Berisiko Remaja di Indonesia menurut Survey Kesehatan Reproduksi Remaja Indonesia ( SKRRI) Tahun 2007 Young Adults Risk Behavior by Indonesia Young Adult Reproductive Health Survey. Jurnal Kesehatan Reproduksi, 1(3), pp.136-144.

Lubis, S,N., 2012. Hubungan Faktor Internal dan Faktor Eksternal dengan Kekambuhan Kembali Proses penyalahgunaan NAPZA di Kabupaten Deli Serdang Tahun 2012. Universitas Sumatera Utara.

Neto, W.B., Silva, A.R.S., Filho, A.J.A., de Lima, L.S., de Aquino, J.M., \& Monteiro, E.M.L.M., 2014. Educational Intervention on Violence with Adolescents: Possibility for Nursing in School Context. Escola Anna Nery Revista de Anfermagem, 18(2), pp.195-201.

Notoatmodjo, S., 2010. Ilmu Perilaku Kesehatan. Jakarta: Rineka Cipta.

Pratama, O.W., 2016. Hubungan Kepercayaan Diri dengan Prestasi Belajar pada Korban Bullying.
Universitas Ahmad Dahlan, Yogyakarta.

Septiyuni, D.A., Budimansyah, D., \& Wilodati., 2015. Pengaruh Kelompok Teman Sebaya ( Peer Group ) Terhadap Perilaku Bullying Siswa di Sekolah. Jurnal Sosietas, 5(1).

Shlafer, R.J., McMorris, B.J., Sieving, R.E., \& Gower, A.L., 2014. The Impact of Family and Peer Protective Factors on Girls' Violence Perpetration and Victimization. J Adolescent Health, 52(3), pp.365-371.

Shofia, Y.N., \& Sari, Y., 2016. Hubungan antara Peran Teman Sebaya dengan Perilaku Bullying pada Siswa Kelas XI di SMAN Z Bandung A Correlational Study of the Relationship between Role of Peer Group and Bullying Behavior the student XI Class at SMAN Z Bandung Peringkat Teratas Pengaduan. In Prosiding Psikologi, 2, pp.636-641.

Sriyanto., Abdulkarim, A., Zainul, A., \& Maryani, E., 2014. Perilaku Asertif dan Kecenderungan Kenakalan Remaja Berdasarkan Pola Asuh dan Peran Media Massa. Jurnal Psikologi, 41(1), pp.74-88.

Sulistyowati, F.S., 2014. Pengaruh Lingkungan Sekolah dan Pengetahuan Terhadap Perilaku Kekerasan di Kalangan Pelajar. Universitas Sebelas Maret.

Sumiati, E., \& Lailan, M., 2012. Identitas Diri Remaja pada Siswa Sma Kartika I-2 Medan. Jurnal Keperawatan Holistik, 1(1), pp.30-34.

Susanti., 2012. Hubungan Jenis Kelamin, Keterpaparan Media dan Pengaruh Teman Sebaya Dengan Perilaku Seksual Remaja di SMPN 6 Palolo Sulawesi Tengah Tahun 2012. Universitas Indonesia.

Usman, I., 2013. Kepribadian, Komunikasi, Kelompok Teman Sebaya, Iklim Sekolah dan Perilaku Bullying. Humanitas, X(1), pp.4959.

Voisin, D.R., Patel, S., Sung, J., Takahashi, L., \& Gaylord-harden, N., 2016. Children and Youth Services Review Behavioral Health Correlates of Exposure to Community Violence Among African-American Adolescents in Chicago. Children and Youth Services Review, 69, pp.97-105.

World Health Organization., 2015. Preventing Youth Violence: An Overview of the Evidence. Geneva.

Xia, Y., Li, S. D., \& Liu, T.-H., 2018. The Interrelationship between Family Violence , Adolescent Violence, and Adolescent Violent Victimization: An Application and Extension of the Cultural Spillover Theory in China. International Journal of Environmental Research and Public Health, 
Erni Gustina, et al / Violance Determinant on Teenager in Yogyakarta

25(371), pp.2-15.

Yandri, H., 2014. Peran Guru BK/Konselor dalam
Pencegahan Tindakan Bullying di Sekolah. Jurnal Pelangi, 7(1), pp.97-107. 